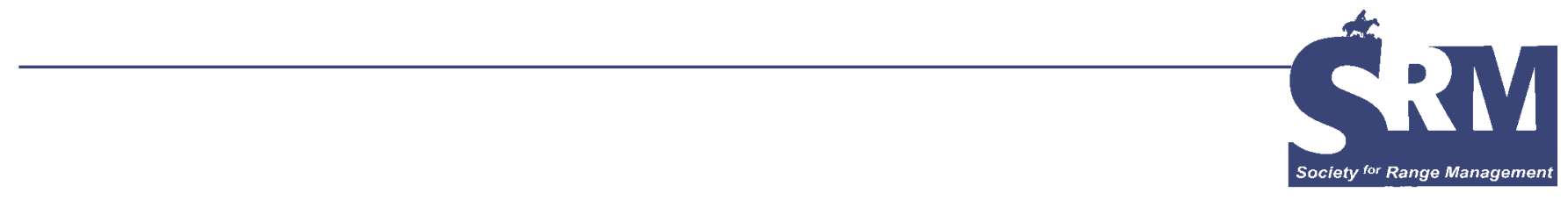

\title{
A Conversation With Margaret Friedel
}

\section{By Thad Box}

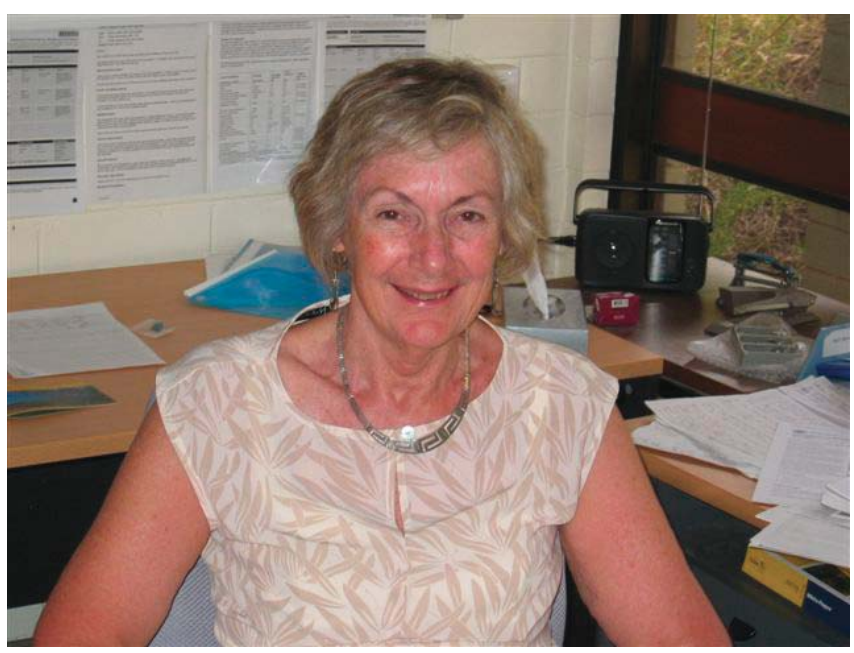

Margaret Friedel.

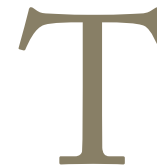

he first time I saw Margaret Friedel she was a pert young woman in a miniskirt. That was long ago in Australia where blokes called girls "birds" and women had trouble buying a beer in an Outback public bar. Marg was one of a small but growing number of women in Australian science. Working on rangelands was especially rare for women since such work was done in the field under harsh conditions.

Today, Marg is a respected senior scientist in the Commonwealth Scientific and Industrial Research Organization (CSIRO) and the group leader of the rangeland lab at Alice Springs, in Central Australia. She is one of the most experienced scientists working on arid rangelands worldwide. She is known in America, Asia, Africaanywhere rangelands occur. SRM members probably know her best from her pioneering work on state and transition ecology.

In January I had a yarn with Marg in her lab at Alice Springs. I lack the interviewing ability and the writing skills of Susan McGuire, but what Marg had to say should be heard by range people everywhere. It is especially relevant for young people wanting to join land care professions. So with apologies to Ms. McGuire, here are some of the things Marg and I talked about.

\section{TB: How did a kid like you get started in rangelands work?}

MF: It just sort of happened. I did my $\mathrm{PhD}$ at the University of Melbourne working on nutrient cycling in pine plantations. Then I took a temporary job teaching teachers about the outdoors, which lasted three years. I loved working outdoors and sleeping in tents but it was pretty bleak in winter up in the mountains, week after week. One day I decided I should improve my life in two ways - get back to nutrient cycling work and go where it was warm. I applied for an ecologist position with CSIRO in Alice Springs. I came here in 1974. I found my place and have been here ever since.

\section{TB: How was a woman scientist accepted in those days?}

MF: The other scientists treated me very well, with few exceptions. In some cases I think they tried to protect and encourage me. My boss, Ray Perry, was very supporting. Some of the technicians wondered if I'd expect special treatment working out bush but we got on well. There had been women scientists in Alice Springs before, so I was not 
unique. The challenge was not so much being a woman scientist as being a woman in outback Australia, which was still a 'man's world'.

\section{TB: You're a long-time member of the SRM. Why do you think it important to belong to a foreign professional group?}

MF: Professional societies are very important. In addition to SRM, I belong to the Grassland Society of Southern Africa. I was a charter member of the Australian Rangeland Society and was its first woman president. Societies don't just publish our science. Their activities make us think more broadly about rangelands.

These societies have several roles that are not often talked about. They tend to bring like-minded people together and form networks and communities of people who have a common purpose. You can't get that just from the literature. Getting to know one another, sharing opportunities, and understanding other approaches to similar problems are part of the annual gatherings.

Societies have a responsibility to get their members thinking about rangelands in a number of different ways. Scientists can benefit from perceptions of artists and other professions. For instance, artist Mandy Martin, with her pastoralist (rancher) husband Guy Fitzhardinge and others, have published books of her paintings with essays about the land, which enable us to appreciate in a different way what rangelands are about.

At one of our ARS conferences historian Tom Griffiths brought to life the Royal Commission conducted in 1900 into the deterioration of the Western Division of New South Wales. Acting as the Commissioner, he called on members of the audience to stand up and present the evidence of pastoralists and politicians. Through making that old document live, they gave those of us today a better insight into how quickly the land changed after settlement, when people didn't understand the limitations of the environment.

There are many different ways societies can give their members a feeling for its history, the beauty of the landscape, and the personal attachment to the land. Understanding the different values people hold for the land is an important part of making workable decisions and policy about future use. That informal broadening of understanding is every bit as important as the journals societies publish.

\section{TB: What are some of the ways your job has} changed since 1974?

MF: When I first started to work here, most of the work was done by fairly discipline-focused scientists. Our goal was to produce good science and publish our work with the expectation that it would be useful for governments and landholders. Today our work is mostly done in teams with a broader suite of skills, often incorporating ecological, social, and economic knowledge, so that we can take into account the different values which drive the management of land. Engagement with end users of research is much more 'up front.' For example, I am currently involved in researching peoples' perceptions of management options for buffelgrass, so that our management recommendations have the best chance of being taken up.

As a result there's wider acceptance among pastoralists that ecological research can be helpful to them. When I started out, pastoralists were tolerant of me working on their land but some chuckled about why I wanted to work on 'weeds' (that is, vegetation). On the other hand, there were others who were very knowledgeable about their vegetation and they still teach me things about their land. We are also working with a much wider variety of end users, including Aboriginal people living on their traditional lands, conservation and tourism agencies, and the mining industry, and our focus is on sustainable livelihoods.

We now have the tools to work with large amounts of data and across many disciplines. For example we are able to recognize and research landscape scale processes with remotely sensed data, which means we can work at scales which are relevant to management. It's now relatively easy to integrate ecological, economic and social information for reporting on the status of rangelands. We have better communication between groups and labs to overcome any problems of distance between us.

On the negative side, we now have more regulations, more administrative details. But that is another story.

\section{TB: You are probably best known in America for your pioneering work in state and transition concepts. How did that come about?}

MF: It certainly didn't originate with me. There were a number of people, especially in arid lands, who were observing that concepts we had been taught like succession and climax did not adequately explain what we were seeing.

We here in Central Australia were working with processes that occurred on a very broad spatial scale. We are in an environment with very little certainty-rainfall is low and can come in any season of the year. In some years fires create new spatial and temporal patterns which overlay landscape patterns and interact with more spatially fixed effects on grazing. What we saw were not the patterns and processes described for the more humid zones; 'climax' was instead a moving target.

Once the idea of states and transitions reached the scientific journals, people began to think about arid lands in a new way. The idea really helps as a way of conceptualizing the possible outcomes of management actions and for identifying warning signs, but it has practical limitations. On the ground there can be parts of a large pasture or paddock that are in different states, so that, viewed at a larger scale, there is more of a continuum. It was sometimes a bit frustrating to go to meetings where someone described in fine detail lots of states in a small area, which probably couldn't be 
generalized enough to be useful across a broader landscape. On the other hand, modeling and new applications should ensure that the concepts remain relevant or are replaced with something better.

\section{TB: How have Australia's arid lands changed in your time here?}

MF: There's a lot more vegetation here now. I never really saw the barren rangelands shown in pictures of Central Australia taken during the drought of the 1960s. By the time I arrived in 1974, many of the ranges were recovering, although whether they recovered to the state they'd been in before I can't say. Above average rain kept coming until 1978 , so there was green grass almost continuously and the country looked pretty good. Another reason it looked good was that stocking rates were better kept in tune with carrying capacity. A campaign to eradicate TB (tuberculosis) and brucellosis meant that pastoralists put in more fencing and managed their cattle more closely in many areas.

Like some arid areas in your country, there has been a considerable increase in shrubs and woody plants. There has also been an increase in perennial grasses that almost completely disappeared during the drought years due to the intense dry or to grazing. Even our spinifex grasses that only a termite could eat began to die in that drought.

The biggest change in the grass vegetation has come from a single invasive plant, buffelgrass. There had been scattered stands of a naturalized, low-growing buffelgrass for years, but it did not spread a great deal. During and after the drought there were a number of cultivars of buffelgrass brought in by state and federal agencies to improve the ranges. Some of these cultivars spread along the watercourses, up the trails, and along roadways. Now it is widely established in native plant stands and continues to spread.

We get a pulse of buffelgrass spread during high rainfall periods as well as gradual expansion at other times. Coarse-scale modeling shows that it has the potential to spread through over $60 \%$ of Australia although not every part of the landscape within that $60 \%$ will be suitable.

Probably the greatest threat is that buffelgrass provides an increased fuel load that can carry a fire in areas that seldom burned. It has the potential for changing much of
Australian rangelands, through elimination of trees and shrubs and dominance of the ground vegetation.

\section{TB: What do you see as the future for Australia's rangelands?}

MF: The pastoral industry will continue, but there will be ongoing rethinking about how rangelands are used. Livestock will continue to be a major product, but increasingly there will be other uses.

The cultural and social landscapes will change. Under pastoral use, each station (ranch) has only a few people - the owner's family and a few hands to help run the livestock. Now some properties may be occupied by communities of Aboriginal people supported by industries other than cattle raising. Other properties may be managed on a 'stewardship' basis to meet different goals. A number of conservation trusts have bought properties which are managed for environmental and, in some cases, tourism values.

Desert landscapes will be changed long term. They will probably be more uniform with the loss of some of their diversity. Invasive species, like the buffelgrass I talked about earlier and feral camels will continue to increase. But our rangelands will still be some of the most wonderful places in the world.

TB: What do you have to say to young people who may consider a career in rangelands?

MF: Rangeland work really represents an open door. There are lots of ways to enter into interesting careers, and once you are through the door, you won't want to leave. This kind of country has an attraction no other does. This environment inspires people in all areas-ecological and social sciences, economics, theater, art, industry. Once you work in rangelands, you will find it hard to leave.

\section{TB: And what would you say to SRM members?}

MF: Talk to one another. Tell the story of the land and its people. It is important to have a continuing dialog about the land. We must pass along our knowledge about how to integrate culture and land.

Author Thad Box can be reached by e-mail: thadbox@comcast. net. 